Orissa Journal of Commerce

Vol. 42, Issue 3, July-September 2021

ISSN: 0974-8482

(C) OJC India. All Right Reserved

URL: www.ojcoca.org

DOI: https://doi.org/10.54063/ojc.2021.v42i03.07

\title{
Corporate Social Responsibility Initiatives in Indian Corporate Sector: An Empirical Investigation from Employees Perspective
}

\author{
Vishal Anand ${ }^{1 *}$ and Mukesh Kumar ${ }^{2}$ \\ ${ }^{1}$ Research Scholar, Chaudhary Charan Singh University, Meerut, Uttar Pradesh. E-mail: vishaldigital81@gmail.com \\ ${ }^{2}$ Associate Professor, Department of Commerce, J.V. Jain (P.G.) College, Saharanpur, Uttar Pradesh. \\ E-mail: drmukeshkumar012@gmail.com \\ ${ }^{*}$ Corresponding Author
}

To cite this paper

Anand, V., \& Kumar M. (2021).

Corporate Social Responsibility Initiatives in Indian Corporate

Sector: An Empirical Investigation from Employees Perspective.

Orissa Journal of Commerce. 42(3), 85-95.

Keywords

Corporate social responsibility,

Employee perception, India,

Stakeholder theory, CSR

performance outcomes

JEL Classification M14, M10, G30, G38, Q01

\begin{abstract}
This study investigates the perception of employees regarding the indulgence of their company in CSR initiatives. It also attempted to highlight the corporate social responsibility initiatives adopted and various thematic areas of CSR like education, health, environment protection, rural development, and community development, etc. This study is based on the stakeholder theory of corporate social responsibility where CSR is meant to provide benefits to various stakeholders like employees, customers, suppliers, neighbouring communities, government, society, nation, and the whole planet. So, to address the gap, the current research article studied CSR from an employee's point of view and investigated whether employees differ in perception regarding various CSR initiatives adopted by their company. The findings suggest that employee's perception is not significantly different regarding CSR initiatives and thematic areas. Each employee responded positively regarding their company's involvement in social and environmental projects.
\end{abstract}

\section{Introduction}

CSR is a phenomenon which is highly debated for the past few decades. There are numerous theories and models propounded by researchers and academicians like Carroll's CSR pyramid 1991, Liberal theory by Friedman in 1970, stakeholder theory by Freeman in 1984, Triple bottom line by Elkington in 1994, so on and so forth. From the standpoint of stakeholder theory, a vast number of empirical researches on Corporate Social Responsibility (CSR) have been done (Carroll, 1991; Boadi et al., 2018; Berg et al., 2018). As per the stakeholder hypothesis, businesses must serve the various categories of people who have a vested interest in their operations (Porter and Kramer, 2013). Stakeholders are defined as everyone who is impacted by or has the power to influence the conduct of a firm (Donaldson and Preston, 1995). Workers seem to remain the most essential factors in the execution of CSR because they are the players who turn CSR efforts into a variety of organizational outcomes. This implies that workers can influence public perception of their company's CSR efforts (Lee et al., 2013; Meyer, 2015; Story and Neves, 2015; Gkorezis and Petridou, 2017). 
As the origination of stakeholder theory, it was developed in 1990 in response to the understanding that all firms and organizations must play a part in social development in addition to maximizing their profits. The concept argues that firms should operate in such a way that they meet the expectations of stakeholders linked with the company in some way. Organizations should prioritize good governance by implementing a variety of approaches.

Mueller et al. (2012) asserted that the use of CSR has been thoroughly researched. There is a plethora of information available on corporate social responsibility. However, when it comes to the perception of CSR efforts and CSR performance results, some studies use a fragmented methodology to measure only one or a few components of performance outcomes. Existing research has established a link between employee perception of CSR efforts and financial performance (Waddock and Graves, 1997; McWilliams and Siegel, 2001), corporate engagement (Ali et al., 2011; Stancu et al., 2011; Lee et al., 2013) organizational performance (Lee et al., 2013; Ahmad and Rahim, 2005); perception and attitude of investors (Graves and Waddock, 1994; Coffey and Fryxell, 1991; Johnson and Greening, 1999), marketing and consumer view (Vaaland et al., 2008; Maignan and Ferrell, 2001), and employees job perspectives (Greening and Turban, 2000).

Certain performance results are associated with CSR's justification. CSR provides value to organizations in terms of better image, prosperity, and competitiveness in its concrete implementation. Employees gain in terms of increased morale \& productivity, engagement \& skill enhancement and contentment. CSR is unquestionably advantageous to the protection of the environment and the preservation of natural resources. It assists investors by providing them with accurate knowledge and profits. It benefits customers as well as society as a whole. Several more advantages are received to commercial sectors by sharing their wealth with society and community. So, in the current study, an attempt has been made to examine and predict CSR performance results using employees' perceptions of CSR activities.

\section{Review of Literature}

Carroll (1991) proposed categorizing CSR into four categories; specifically, the overall corporate social responsibility of a corporation entails the concurrent fulfillment of the particular financial, legislative, moral, and charitable duties. Wheeler and Sillanpaa (1997) postulated that CSR is rooted in stakeholder theory, which is an elaboration of Freeman (1984) and Carroll (1991) contributions. The basic concept of stakeholder theory is that a company's long-term worth is based on its employees' expertise, abilities, and devotion just as much as, it is on its connections with customers, suppliers, investors, and other stakeholders.

According to Campbell et al. (1999), culture influences employee productivity and effectiveness in terms of job quality. Culture impacts work ethics, moral attitudes, ethical orientations, and business values which impact CSR assessment. Company culture influences social structures as well as employee behaviors, morale, and motivation. CSR and corporate ethics are intricately linked. Porter and Kramer (2006) in their study postulated numerous variables that influence the strategic implementation of CSR, like corporate cultural values and societal needs and expectations. Employees recognize CSR activities favorably and constructively once these factors have compiled. Employee perception of CSR 
activities is critical in expanding devotion and reducing internal turnover. According to Ali et al. (2011), CSR activities are meant to provide numerous benefits including attainment of business goals, customer service, organizational commitment, etc which leads to enhanced organizational performance.

Van Marrewijk (2003) emphasized the close relationship between CSR and sustainability, as well as the fact that a company's socially responsible intentions support it obtaining a competitive advantage in the market. Furthermore, the company employs them to increase profits while also assisting the community. According to the findings, no firm can survive without addressing client and employee sustainability policies. He provided an overview of the current debate over CSR and corporate sustainability concepts and terminology (CS).

Stancu et al. (2011) recognized Employee commitment as an essential construct having an impact on effective CSR adoption. According to the findings of the study, the quality of a product or service is determined by employees education, motivation, and training. Increased employee motivation and adequate training help a firm to build good relationships with internal stakeholders and, as a result, enhance profit margins. The author highlighted the importance of employee volunteerism as workers' engagement in CSR initiatives in the study. Lee et al. (2013) in their study state that CSR is connected with more favorable opinions regarding the organization. Being the major stakeholders, employees have a direct impact on a company's viability. CSR studies in the past have included group or individual employee views and outcomes as a result of CSR activities. An integrated framework has been developed to describe how CSR initiatives result in employee CSR perception development.

Latif and Sajjad (2018) studied and discussed survey techniques for assessing stakeholders' attitudes toward social responsibility (CSR). In order to build an effective research instrument, a detailed review of research was undertaken. A total of 43 structured questions were used to analyze participants' CSR perspectives. In addition, the analysis revealed that there are shared dimensions i.e. financial, regulatory, moral, charitable, social, and environmental duties. This study expands on the CSR topic by proposing a number of options for constructing survey instruments to assess participants' views on CSR.

\section{Objectives and Hypotheses of the Study}

\subsection{Objectives of the Study}

The main objectives of this study are:

- To analyze the employees' perception on CSR initiatives of selected industries under the Indian corporate sector.

- To analyze, whether various CSR initiatives have an impact on corporate social performance.

\subsection{Hypotheses of the Study}

Based on the extant literature and objectives, the authors proposed the following hypotheses:

$\mathrm{H}_{01}$ : There is no significant difference in employees' perception about CSR initiatives in Selected Industries under Indian corporate sector.

$\mathrm{H}_{02}$ : CSR initiatives do not have any impact on various corporate social performance measures. 


\section{Research Methodology}

An empirical study was conducted to investigate the perception of employees regarding CSR initiatives and CSR performance outcomes. Primary data was collected from the employees of 20 reputed companies from 5 distinct sectors like Automobile, Banking, Petroleum \& Natural Gas, FMCG, and IT sectors to determine the level of CSR initiatives adopted by them and subsequently their impact on CSR performance outcomes (organizational performance, and employee commitment \& satisfaction). These companies are selected, based on their outstanding contribution in the field of CSR and their presence in Futurescape responsible business ranking 2020. A self-administered questionnaire was designed to collect responses from the employees on a five-point Likert scale. The questionnaire is adapted and modified from the questionnaires used by Carroll (1991); Maignan and Ferrell (2001); Cable and DeRue (2002); Kanji and Chopra (2010); Iqbal et al. (2012); Lee et al. (2013); Choi and Yu (2014); Huang (2016); Gao and He (2017); Latif and Sajjad (2018). Descriptive analysis, one-way ANOVA, and Regression modeling were applied to test the hypotheses.

\section{Data Analysis and Findings}

The data was analyzed and discussed with the help of both descriptive and inferential statistics.

\subsection{Difference among Perceptions of Employees Regarding CSR Initiatives}

Table 1: Analysis of Employee's Perception Regarding Various CSR Initiatives in Selected Sectors under Study (Descriptive Analysis and One-way ANOVA)

\begin{tabular}{lllrrrrrrr}
\hline Sector & $N$ & Descriptive & HSPE* & ETLE* & ES* & $R D^{*}$ & $C^{*}$ & DUS* & PACSD* \\
\hline Automobile sector & 65 & Mean & 4.12 & 4.18 & 4.2 & 4.18 & 4.13 & 4.12 & 4.17 \\
& & SD & 0.49 & 0.5 & 0.48 & 0.5 & 0.54 & 0.52 & 0.44 \\
Banking sector & 74 & Mean & 4.14 & 4.16 & 4.27 & 4.08 & 4.18 & 4.12 & 4.14 \\
& & SD & 0.52 & 0.5 & 0.46 & 0.62 & 0.54 & 0.57 & 0.54 \\
Petroleum and & 63 & Mean & 4.19 & 4.19 & 4.2 & 4.13 & 4.17 & 4.13 & 4.19 \\
Natural Gas sector & & SD & 0.51 & 0.46 & 0.52 & 0.54 & 0.61 & 0.52 & 0.39 \\
FMCG sector & \multirow{2}{*}{ M1 } & Mean & 4.11 & 4.15 & 4.15 & 4.15 & 4.08 & 4.08 & 4.08 \\
& & SD & 0.54 & 0.54 & 0.62 & 0.57 & 0.53 & 0.58 & 0.54 \\
IT & \multirow{2}{*}{70} & Mean & 4.19 & 4.18 & 4.2 & 4.17 & 4.18 & 4.13 & 4.2 \\
Sector & & SD & 0.46 & 0.46 & 0.44 & 0.46 & 0.44 & 0.52 & 0.45 \\
Total & \multirow{2}{*}{343} & Mean & 4.15 & 4.17 & 4.21 & 4.14 & 4.15 & 4.12 & 4.16 \\
& & SD & 0.5 & 0.49 & 0.51 & 0.54 & 0.53 & 0.54 & 0.48 \\
F Ratio & & 0.395 & 0.091 & 0.518 & 0.356 & 0.443 & 0.1 & 0.714 \\
Sig & & 0.812 & 0.989 & 0.722 & 0.84 & 0.778 & 0.982 & 0.583 \\
\hline
\end{tabular}

Source: Authors' Compilation from Primary Data

*Note: HSPE: Heath, Sanitation and Poverty Eradication; ETLE-Education, Training and Livelihood Enhancement; ES-Environment Sustainability; RD-Rural Development; CD-Community Development; DUS-Development of Underprivileged section; PACSD-Promotion of Arts, Culture, Sports and Donation. 
Table 1 exhibits the employee's perception towards various CSR initiatives in selected industries in the Indian corporate sector. Descriptive analysis and ANOVA were calculated. As depicted in Table 1, the mean score of perception of employees in the petroleum \& natural gas sector (4.19) and IT sector (4.19) is highest in the case of the health, sanitation \& poverty eradication (HSPE) construct. In the case of education, training, and livelihood enhancement, the mean score of perception of employees is highest in petroleum \& natural gas sector (4.19). Simultaneously in the case of other variables, different sectors have shown the highest agreement regarding different CSR initiatives.

ANOVA is calculated to test the difference among sectors regarding CSR initiatives. Results are shown in the form of an $\mathrm{F}$ ratio and $\mathrm{p}$-value. It is observed that all the sectors do not differ significantly as far as the employee's perception regarding CSR initiatives are concerned as the p-value is $>0.05$ and whatever the difference exists that is due to sampling fluctuations or by chance.

\subsection{Analysis of Sample Respondents based on their Demographic Characteristics}

Table 2: Demographic Characteristics of Sample Respondents Under Study

\begin{tabular}{|c|c|c|c|c|c|c|c|}
\hline $\begin{array}{l}\text { Demographic } \\
\text { Variable }\end{array}$ & Categories & Automobile & Banking & $\begin{array}{l}\text { Petroleum and } \\
\text { Natural Gas }\end{array}$ & FMCG & $I T$ & Total \\
\hline \multirow[t]{2}{*}{ Gender } & Male & 39 & 34 & 38 & 37 & 32 & 180 \\
\hline & Female & 26 & 40 & 25 & 34 & 38 & 163 \\
\hline \multirow[t]{5}{*}{ Age } & $<25$ & 3 & 5 & 2 & 5 & 4 & 19 \\
\hline & $25-35$ & 20 & 24 & 12 & 37 & 27 & 120 \\
\hline & $36-45$ & 22 & 25 & 30 & 19 & 23 & 119 \\
\hline & $46-55$ & 14 & 16 & 15 & 9 & 11 & 65 \\
\hline & $>55$ & 6 & 4 & 4 & 1 & 5 & 20 \\
\hline Educational & Graduation & 3 & 9 & 0 & 10 & 12 & 34 \\
\hline \multirow[t]{4}{*}{ Qualification } & Post graduation & 21 & 38 & 44 & 28 & 23 & 154 \\
\hline & Professional & 38 & 27 & 19 & 27 & 33 & 144 \\
\hline & Ph.D & 1 & 0 & 0 & 3 & 0 & 4 \\
\hline & Others & 2 & 0 & 0 & 3 & 2 & 7 \\
\hline \multirow[t]{2}{*}{ Job Position } & Managerial & 9 & 14 & 15 & 6 & 8 & 52 \\
\hline & Non- Managerial & 56 & 60 & 48 & 65 & 62 & 291 \\
\hline Total Working & $<5$ years & 21 & 16 & 3 & 9 & 13 & 62 \\
\hline \multirow[t]{3}{*}{ Experience } & $5-10$ years & 12 & 16 & 28 & 46 & 34 & 136 \\
\hline & $10-15$ years & 23 & 30 & 22 & 12 & 14 & 101 \\
\hline & $>15$ years & 9 & 12 & 10 & 4 & 9 & 44 \\
\hline
\end{tabular}

Source: Authors' Compilation from Primary Data

This study is based on the respondents from various sectors having different demographic characteristics. The above table presents the demographic profile of the respondents. Total 343 respondents were included in the study out of which 65 were from the automobile sector, 74 from the 
Vishal Anand and Mukesh Kumar

banking sector, 63 from petroleum \& natural gas sector, 71 from the FMCG sector, and 70 from the IT sector.

\subsection{CSR Initiatives (Consolidated) Predicting Organizational Performance}

Table 3: Regression Analysis to Study the Impact of CSR Initiatives (Consolidated) on Organizational Performance

\begin{tabular}{lrrrrrrr}
\hline Model & $\mathrm{R}$ & $\mathrm{R}^{2}$ & $\mathrm{R}^{2}$ Change & F Change & df1 & df2 & Sig. F Change \\
\hline Regression & 0.744 & 0.554 & 0.554 & 423.247 & 1 & 341 & 0.001 \\
\hline
\end{tabular}

Source: Authors' Compilation from Primary Data

Table 4: ANOVA Table of Regression Model Significance

\begin{tabular}{lrrrrr}
\hline Model & Sum of Squares & Df & Mean Square & $F$ & Sig. \\
\hline Regression & 25.038 & 1 & 25.038 & 423.247 & 0.001 \\
Residual & 20.173 & 341 & 0.059 & & \\
Total & 45.211 & 342 & & & \\
\hline
\end{tabular}

Source: Authors' Compilation from Primary Data

(Dependent Variable: Organizational Performance, Predictors: (Constant), CSR Initiatives consolidated)

Table 5: Coefficients of Un-standardized and Standardized Beta with $\mathrm{t}$ and $\mathrm{p}$-value

\begin{tabular}{lrcccr}
\hline Model & $\begin{array}{r}\text { Unstand. } \\
\text { Coefficients B }\end{array}$ & SE & $\begin{array}{c}\text { Standard. } \\
\text { Coefficients Beta }\end{array}$ & T & Sig. \\
\hline Constant & 1.759 & 0.121 & & 14.552 & 0.001 \\
Overall CSR Initiatives & 0.595 & 0.029 & 0.744 & 20.573 & 0.001 \\
\hline
\end{tabular}

Source: Authors' Compilation from Primary Data

(Dependent Variable: Organizational Performance)

The regression model predicts the values of dependent variables with the help of independent variables with $\left(\mathrm{R}^{2}=0.554\right)$ which is highly significant and positive. From tables no- 3 , 4 , and 5 , the Model exhibits that when all the CSR initiatives are taken collectively then they contribute 55.4\% variation in Organizational performance. The individual contribution of independent constructs towards Organizational performance is measured with the help of beta and can be elaborated based on $\mathrm{p}$ or $\mathrm{t}$ values. Collective CSR initiatives with beta value (beta $=0.595, \mathrm{t}=20.573$ and $\mathrm{p}=0.001$ ) indicate significant contribution toward dependent variables as $\mathrm{p}<0.05$. From the coefficients, the regression equation can be written in the following manner: 
Corporate Social Responsibility Initiatives in Indian Corporate Sector

Organizational Performance $=1.759+0.595$ (Consolidated CSR Initiatives)

ANOVA table presents the significance of model summary stating that the regression results are significant with $\mathrm{F}(1,341)=423.247, \mathrm{p}=0.001$, and CSR initiatives (consolidated) predict the Organizational performance. This way the impact of CSR initiatives is studied on Organizational performance.

\subsection{CSR Initiatives (Consolidated) predicting Employees Commitment E Satisfaction}

Table 6: Regression Analysis to Study the Impact of CSR Initiatives (Consolidated) on Employees Commitment \& Satisfaction

\begin{tabular}{lrrrrrrr}
\hline Model & $\mathrm{R}$ & $\mathrm{R}^{2}$ & $\mathrm{R}^{2}$ Change & F Change & df1 & df2 & Sig. F Change \\
\hline Regression & 0.802 & 0.644 & 0.644 & 616.6 & 1 & 341 & 0.001 \\
\hline
\end{tabular}

Source: Authors' Compilation from Primary Data

Table 7: ANOVA Table of Regression Model Significance

\begin{tabular}{lrrrrr}
\hline Model & Sum of Squares & Df & Mean Square & F & Sig. \\
\hline Regression & 36.974 & 1 & 36.97 & 616.6 & 0.001 \\
Residual & 20.448 & 341 & 0.06 & & \\
Total & 57.421 & 342 & & \\
\hline
\end{tabular}

Source: Authors' Compilation from Primary Data

(Dependent Variable: Employee commitment \& satisfaction, Predictors: (Constant), CSR Initiatives consolidated)

Table 8: Coefficients of Un-standardized and Standardized Beta with t and p-value

\begin{tabular}{lrrrrr}
\hline Model & $\begin{array}{r}\text { Unstand. } \\
\text { Coefficients B }\end{array}$ & SE & $\begin{array}{r}\text { Standard } \\
\text { Coefficients Beta }\end{array}$ & T & Sig. \\
\hline Constant & 1.168 & 0.122 & 0.598 & 0.001 \\
Overall CSR Initiatives & 0.723 & 0.029 & 0.802 & 24.831 & 0.001 \\
\hline
\end{tabular}

Source: Authors' Compilation from Primary Data

(Dependent Variable: Employee commitment \& satisfaction)

The regression model predicts the values of dependent variables with the help of independent variables with $\left(\mathrm{R}^{2}=0.644\right)$ which is highly significant and positive. From tables no $-6,7$, and 8 , the Model exhibits that when all the CSR initiatives are taken collectively then they contribute $55.4 \%$ variation in Employees commitment \& satisfaction. The individual contribution of independent constructs towards Employees commitment \& satisfaction is measured with the help of beta and can be elaborated based on p or $\mathrm{t}$ values. Collective CSR initiatives with beta value (beta $=0.723, \mathrm{t}=24.831$ 
and $\mathrm{p}=0.01$ ) indicate significant contribution toward dependent variables as $\mathrm{p}<0.05$. From the coefficients, the regression equation can be written in the following manner:

Employees Commitment \& Satisfaction $=1.168+0.723$ (consolidated CSR Initiatives)

ANOVA table presents the significance of model summary stating that the regression results are significant with $\mathrm{F}(1,341)=616.60, \mathrm{p}=0.001$ and CSR initiatives (consolidated) predict the Employees commitment \& satisfaction. This way the impact of CSR initiatives is studied on Employees commitment $\&$ satisfaction.

\section{Results and Implications}

Results of the analysis revealed that employee's perceptions regarding various CSR initiatives do not differ significantly in all sectors under study and it has also resulted that CSR initiatives have a positive relationship with CSR performance outcomes. The impact of CSR initiatives on CSR performance outcomes was also significant. The findings of the present study were matched with the results of existing studies (Orlitzky et al., 2003; Lee et al., 2013, Greening and Turban, 2000, Ahmad and Rahim, 2005). The findings of this paper provide learning for Indian corporations to conduct CSR activities more honestly and cohesively. The findings revealed that the employee perspective of CSR is favorable, and there is no disparity across all sectors studied; this agreement helps managers to improve employee productivity and economic prestige. Directors may develop policies and plans for the innovative and successful implementation of CSR in their organization, as well as rethink CSR projects to improve employee productivity and devotion.

CSR performance outcomes are divided into two variables in the present study like Organizational performance and Employees commitment \& satisfaction. There are various studies that considers the impact of CSR on Organizational performance (Yang, 2018; Bhuiyan et. al., 2020); and the impact of CSR on Employees commitment \& satisfaction (Brammer et al., 2007; Ali et al., 2010; Ellemers et al., 2011; Yahya and Ha, 2013; Gaudencio et al., 2014; Barakat et al., 2016; Khaskheli et al., 2020; Tangngisalu et al., 2020; Carlini and Grace, 2021).

\section{Conclusion}

Societal responsibility practices have really been proved to be closely connected to social results. As a result, the study presents a comprehensive view of social commitments. The research began with the creation of the CSR concept and progressed through Indian business CSR practices and the assessment of employee perceptions. Company social responsibilities have a direct linkage with performance results, which finally have a positive impact on profit, people, and planet.

In conclusion, it can be stated that companies must take an integrated and holistic approach for economic performance and sustainability to interact. Firms must ensure to implement the concept of the triple bottom line, i.e. people, planet, and profit, more seriously. With the advent of the concept of sustainability, social responsibility has become critical to the survival of businesses. Apart from delivering high-quality products at reasonable costs, efforts should be made to make business processes environment friendly, adhere to high labours standards, eliminate human rights violations, alleviate 
poverty and inequality, and promote sustainable livelihoods. To that aim, managers should not regard CSR as a requirement to comply with legislation and societal standards. CSR initiatives, on the other hand, may be a regular approach that is tracked and reviewed to strengthen the employer-employee connection and have a beneficial influence on individual employee productivity and recognition with the business. Recognizing the importance of stakeholder participation, employee commitment in CSR activities appears to be critical for their better execution (Venturelli et al., 2018).

\section{References}

Ahmad, N. N. N, \& Rahim, A. N. A. (2005). Awareness of Corporate Social Responsibility among Selected Companies in Malaysia: An Exploratory Note. Malaysian Accounting Review, 4(1), 11-24. DOI: http://dx.doi.org/ 10.24191/mar.v4i1.320.

Ali, I., Rehman, K. U., Ali, S. I., Yousaf, J., \& Zia, M. (2010). Corporate social responsibility influences, employee commitment and organizational performance. African Journal of Business Management, 4(13), 2796-2801.

Ali, I., Rehman, K. U, \& Akram, M. (2011). Corporate social responsibility and investor satisfaction influence investor loyalty. Actual Problems of Economics, 722(8), 348-357.

Boadi, E. A., He, Z., Bosompem, J., Opata, C. N., \& Boadi, E. K. (2020). Employees' perception of corporate social responsibility (CSR) and its effects on internal outcomes. The Service Industries Journal, 40(9-10), 611632.

Barakat, S. R., Isabella, G., Boaventura, J. M. G., \& Mazzon, J. A. (2016). The influence of corporate social responsibility on employee satisfaction. Management decision.

Berg, N., Holtbrugge, D., Egri, C. P, Furrer, O, Sinding, K., \& Dogl, C. (2018). Stakeholder pressures, CSR practices, and business outcomes in Denmark, Germany, and the Netherlands. European Journal of International Management, 12(4), 472. doi:10.1504/ejim.2018.092846.

Bhuiyan, F., Baird, K., \& Munir, R. (2020). The association between organisational culture, CSR practices and organisational performance in an emerging economy. Meditari Accountancy Research.

Boadi, E. A., Asare, A. O., Wadei, K. A, Bosompem, J., \& Sarpong, E. O. S. (2018). Expanding the discourse: Corporate social responsibility (CSR) and socio-econ omic development. European introduction. Oxford, United Kingdom: Butterworth, Heinemann.

Brammer, S., Millington, A., \& Rayton, B. (2007). The contribution of corporate social responsibility to organizational commitment. The International Journal of Human Resource Management, 18(10), 1701-1719.

Cable, D. M., \& DeRue, D. S. (2002). The convergent and discriminant validity of subjective fit perceptions. Journal of applied psychology, 87(5), 875.

Campbell, D., Stone house, G., \& Houston, B. (1999). Business strategy: An Academic Research, VI (6), 30073033.

Carlini, J., \& Grace, D. (2021). The corporate social responsibility (CSR) internal branding model: Aligning employees' CSR awareness, knowledge, and experience to deliver positive employee performance outcomes. Journal of Marketing Management, 37(7-8), 732-760.

Carroll, A. B. (1991). The pyramid of corporate social responsibility: Toward the moral management of organizational stakeholders. Business Horizons, 34(4), 39-48.

Choi, Y., \& Yu, Y. (2014). The influence of perceived corporate sustainability practices on employees and organizational performance. Sustainability, 6(1), 348-364, ISSN: 2071-1050. 
Coffey, B. S., \& Fryxell, G. E. (1991). Institutional Ownership of Stock and Dimensions of Corporate Social Performance: An Empirical Examination. Journal of Business Ethics, 10(6), 437-444.

Donaldson, T., \& Preston, L. E. (1995). The stakeholder theory of the Corporation: Concepts, evidence, and implications. The Academy of Management Review, 20(1), 65-91.

Elkington, J. (1994). The triple bottom line. Environmental management: Readings and cases, 2.

Elkington, J. (1998). Accounting for the triple bottom line. Measuring Business Excellence.

Elkington, J. (1998). Partnerships from cannibals with forks: The triple bottom line of 21 stcentury business. Environmental quality management, 8(1), 37-51.

Ellemers, N., Kingma, L., van de Burgt, J., \& Barreto, M. (2011). Corporate social responsibility as a source of organizational morality, employee commitment and satisfaction. Journal of Organizational Moral Psychology, 1(2), 97-124.

Freeman, R. E. (1984). Stakeholder management: Framework and philosophy. MA: Manfield.

Freeman, R. E. (1984). Strategic management: A stakeholder approach. Marshfield, MA: Pitman.

Friedman M. (1970). The social responsibility of business is to increase its profits. The New York Times Magazine 13 September, p 32-33, p 122-126.

Gao, Y., \& He, W. (2017). Corporate social responsibility and employee organizational citizenship behavior: the pivotal roles of ethical leadership and organizational justice. Management Decision. ISSN: 0025-1747.

Gaudencio, P., Coelho, A., \& Ribeiro, N. (2014). Organizational CSR Practices: Employees Perceptions and Impact on Individual Performance. International Journal of Innovation Management, 18(04), 1450025.

Gkorezis, P., \& Petridou, E. (2017). Corporate social responsibility and pro-environmental behavior: Organizational identification as a mediator", European Journal of International Management, 11(1), doi:10.1504/ ejim.2017.081248.

Graves, S. B., \& Waddock, S. A. (1994). Institutional owners and corporate social performance.

Greening, D. W., \& Turban, D. B. (2000). Corporate social performance as a competitive advantage in attracting a quality workforce. Business and Society 39(3), 254-280.

Huang, C. (2016). Employees' Perception of Corporate Social Responsibility: Corporate Volunteer and Organizational Commitment. International Business Research; Vol. 9, No. 9; 2016, ISSN 1913-9004 E-ISSN 1913-9012 Published by Canadian Center of Science and Education.

Iqbal, N., Ahmad, N., Sheeraz, M., \& Bashir, N. A. (2012). The impact of perceived corporate social responsibility (CSR) on job attitude and performance of internal stakeholders. International Journal of Human Resource Studies, 2(4), 77-86

Johnson, R. A., \& Greening, D. W. (1999). The effects of corporate governance and institutional ownership types on corporate social performance. Academy Management Journal, 42(5), 564- 576.

Kanji, G. K., \& Chopra, P. K. (2010). Corporate social responsibility in a global economy. Total Quality Management, 21(2), 119-143.

Khaskheli, A., Jiang, Y., Raza, S. A., Qureshi, M. A., Khan, K. A., \& Salam, J. (2020). Do CSR activities increase organizational citizenship behavior among employees? Mediating role of affective commitment and job satisfaction. Corporate Social Responsibility and Environmental Management, 27(6), 2941-2955.

Latif, K. F., \& Sajjad, A. (2018). Measuring corporate social responsibility: A critical review of survey instruments. Corporate Social Responsibility and Environmental Management. doi:10.1002/csr.1630

Lee, E.M., Park, S.Y., \& Lee, H.J. (2013). Employee perception of CSR activities: Its antecedents and consequences. Journal of Business Research, 66(10), pp.1716-1724. 
Maignan, I., \& Ferrell, O. C. (2001). Antecedents and benefits of corporate citizenship: An investigation of French business. Journal of Business Research, 51, 37-51.

McWilliams, A., \& Siegel, D. (2001). Corporate social responsibility: A theory of the firm perspective. The Academy of Marketing Review, 26(1), 117-127.

Meyer, M. (2015). Positive business: Doing good and doing well. Business Ethics European Review. 24, 175-197.

Mueller, N. D., Gerber, J. S., Johnston, M., Ray, D. K., Ramankutty, N., \& Foley, J. A. (2012). Closing yield gaps through nutrient and water management. Nature, 490(7419), 254-257.

Orlitzky, M., Schmidt, F. L., \& Rynes, S. L. (2003). Corporate social and financial performance: A meta-analysis. Organization Studies, 24(3), 403-441.

Porter, M., \& Kramer, M. R. (2006). Strategy and society: The link between competitive advantage and corporate social responsibility. Harvard Business Review, 84(12), 78-92.

Stancu, A., Chelcea, L., \& Baleanu, T. E. (2011). Representing corporate social responsibility. A case study of Romania's Top 100 companies. African Journal of Business Management, 5(6), 2040-2047.

Story, J., \& Neves, P. (2015). When corporate social responsibility (CSR) increases performance: Exploring the role of intrinsic and extrinsic CSR attribution. Business Ethics: A European Review, 24(2), 111-124.

Tangngisalu, J., Mappamiring, M., Andayani, W., Yusuf, M., \& Putra, A. H. P. K. (2020). CSR and firm reputation from employee perspective. The Journal of Asian Finance, Economics, and Business, 7(10), 171-182.

Vaaland, T. I., Heide, M., \& Gronhaug, K. (2008). Corporate social responsibility: investigating theory and research in the marketing context. European Journal of Marketing.

Van Marrewijk, M. (2003). Concepts and definitions of CSR and corporate sustainability: Between agency and communion. Journal of business etbics, 44(2), 95-105.

Venturelli, A., Cosma, S., \& Leopizzi, R. (2018). Stakeholder engagement: An evaluation of European banks. Corporate Social Responsibility and Environmental Management, 25(4), 690-703. https://doi.org/10.1002/ csr.1486

Waddock, S. A., \& Graves, S. B. (1997). The corporate social performance-financial performance link. Strategic Management Journal, 18(A), 303-319.

Wheeler, D., \& Sillanpaa, M. (1997). The stakeholder corporation. London: Pitman.

Yahya, W. K., \& Ha, N. C. (2013). The Relationship between Environmental Issues and Organizational Performance. International Journal of Business \& Society, 14(1).

Yang, C. S. (2018). The effect of CSR practices on organizational performance in the container shipping in Taiwan. International Journal of Shipping and Transport Logistics, 10(2), 181-201. 